\title{
The occurrence of the flat-headed cat Prionailurus planiceps in south-east Sumatra
}

\author{
Mark R. Bezuijen
}

\begin{abstract}
Three incidental sightings of the flat-headed cat Prionailurus planiceps, a little-known species, were made in south-east Sumatra. Sightings were on lowland floodplains in two distinct habitats, primary peat swamp forest and secondary lowland forest, the latter suggesting some tolerance to modified habitats. Sightings were along or near waterways. A dead adult male found in Berbak National Park is the first confirmed record for the park. Morphometrics of this individual were consistent with other published measurements for the species. Museum specimens indicate a wide historic distribution
\end{abstract}

\section{Introduction}

The flat-headed cat Prionailurus planiceps Vigors and Horsfield, 1827, is a small felid restricted to Indonesia, Malaysia, Thailand and possibly Myanmar (Nowell \& Jackson, 1996). The International Union for Conservation of Nature (IUCN)-World Conservation Union considers the species 'vulnerable' (Baillie \& Groombridge, 1996), although no research has been conducted in the wild, and a high priority has been given to obtain information on wild populations (Nowell \& Jackson, 1996). This note describes habitats in two locations in south-east Sumatra where flat-headed cats were observed (1995 and 1996), presents some morphological information on the species, and summarizes information on its status and distribution in south-east Sumatra.

\section{Sighting localities and habitat}

Secondary lowland forest and scrub, Merang River, South Sumatra Province

Two flat-headed cats were observed by spotlight at 23:00 h, $40 \mathrm{~km}$ upstream from the mouth of the Merang River (1 $\left.{ }^{\circ} 59^{\prime} \mathrm{S}, 104^{\circ} 00^{\prime} \mathrm{E}\right)$ (Fig. 1), on 15 September 1995. The individuals were on opposite banks and $100 \mathrm{~m}$

Mark R. Bezuijen Wildlife Management International Pty Limited, PO Box 530, Karama, NT 0812. Current address: Ecology Australia Pty Ltd, 272-276 Heidelberg Road, Fairfield, Victoria, Australia 3078. E-mail: ecology@ozemail.com.au

Revised manuscript accepted for publication 15 March 2000 in south-east Sumatra. Recent information confirms the species's presence in protected areas of eastern, southern and western Sumatra, although this is mostly limited to presence/absence data, and the conservation status and habitat requirements of the species in south-east Sumatra are unknown. Regional degradation of riparian habitats and the isolation of protected areas warrant concern for the conservation status of the species.

Keywords Conservation, flat-headed cat, floodplains, Sumatra, swamp forest.

apart. The Merang River is $66 \mathrm{~km}$ long and is a freshwater tributary subject to tidal influence. From the mouth to $45 \mathrm{~km}$ upstream, the river has been modified by logging and burning, and supports secondary forest (c. $10 \mathrm{~m}$ high), scrub ( $3-5 \mathrm{~m}$ ) and grasses, with portions of cleared or burnt banks. Sidecreeks are few in number and are typically narrow ( $<1 \mathrm{~m}$ wide), shallow $(<0.5 \mathrm{~m}$ deep) and drain completely at low tide. Most land adjacent to the river is dry and firm. In 1996, a logging factory was located $42 \mathrm{~km}$ upstream from the mouth and a small village of $50-60$ people was situated $45 \mathrm{~km}$ upstream. This portion of the river is subject to regular human activity, including motorized and nonmotorized boat traffic, vegetation clearance, firewood collection and fishing.

The upper reaches $(46-66 \mathrm{~km})$ have been less heavily logged, have not been burnt, and retain extensive stands of peat swamp forest. There are no permanent human residences in this area. No flat-headed cats were observed in this section of the river.

\section{Primary freshwater swamp forest, Berbak National} Park, Jambi Province

A dead flat-headed cat was examined on 19 September 1996. The specimen had been captured the previous night in primary freshwater swamp forest by villagers, $0.5 \mathrm{~km}$ west of Gajah Creek ( $1^{\circ} 25^{\prime} \mathrm{S}, 104^{\circ} 22^{\prime} \mathrm{E}$; Fig. 1), a tributary of the Air Hitam Laut River. Canopy height is 15-35 $\mathrm{m}$, with an open, sparsely vegetated forest floor. There are few sidecreeks along the Air Hitam Laut River near the capture site, and land adjacent to the river is relatively dry. 
Berbak National Park encompasses more than 171,000 ha of peat swamp, palm swamp and freshwater swamp forest, with possibly the most intact peat swamp forest remaining in south-east Asia (Davie \& Sumardja, 1997). Various reports describe the vegetation, fauna, soils and conservation value of this region (de Wulf et al., 1982; Silvius et al., 1984; Giesen, 1990). The area of Berbak where the cat was captured is subject to infrequent human visitation.

\section{Morphology}

\section{Berbak National Park}

The dead flat-headed cat from Berbak National Park was sufficiently intact to obtain some morphological data and a description of body parts. Measurements were made using electronic digital callipers (to $1 \mathrm{~mm}$ ) except for total length and head-body length, which were measured with a metal tape rule (to $1 \mathrm{~mm}$ ). Body weight was measured with a $25 \mathrm{~kg}$ balance (to $0.1 \mathrm{~kg}$ ), corrected for scale error. Head-body length, head length and tail length measures are as defined by Kitchener et al. (1996) (Table 1).

There were no external injuries, and pelage colour and pattern conformed to previous descriptions (Lim \& Rahman, 1961; Muul \& Lim, 1970; Lekagul \& McNeely, 1977; Nowell \& Jackson, 1996). The dentition also matched previous descriptions, but one carnassial tooth and two upper incisors were missing. The upper canines were worn and rounded, and the lower canines were pointed and only slightly worn. The carnassial teeth were sharp, with little apparent wear. The pelage was in good condition and no external abnormalities or parasites were apparent.
Fig. 1 South-east Sumatra. Historic and current records of the flat-headed cat Prionailurus planiceps are widely distributed over the region, from a range of modified rivers and protected areas (inset)

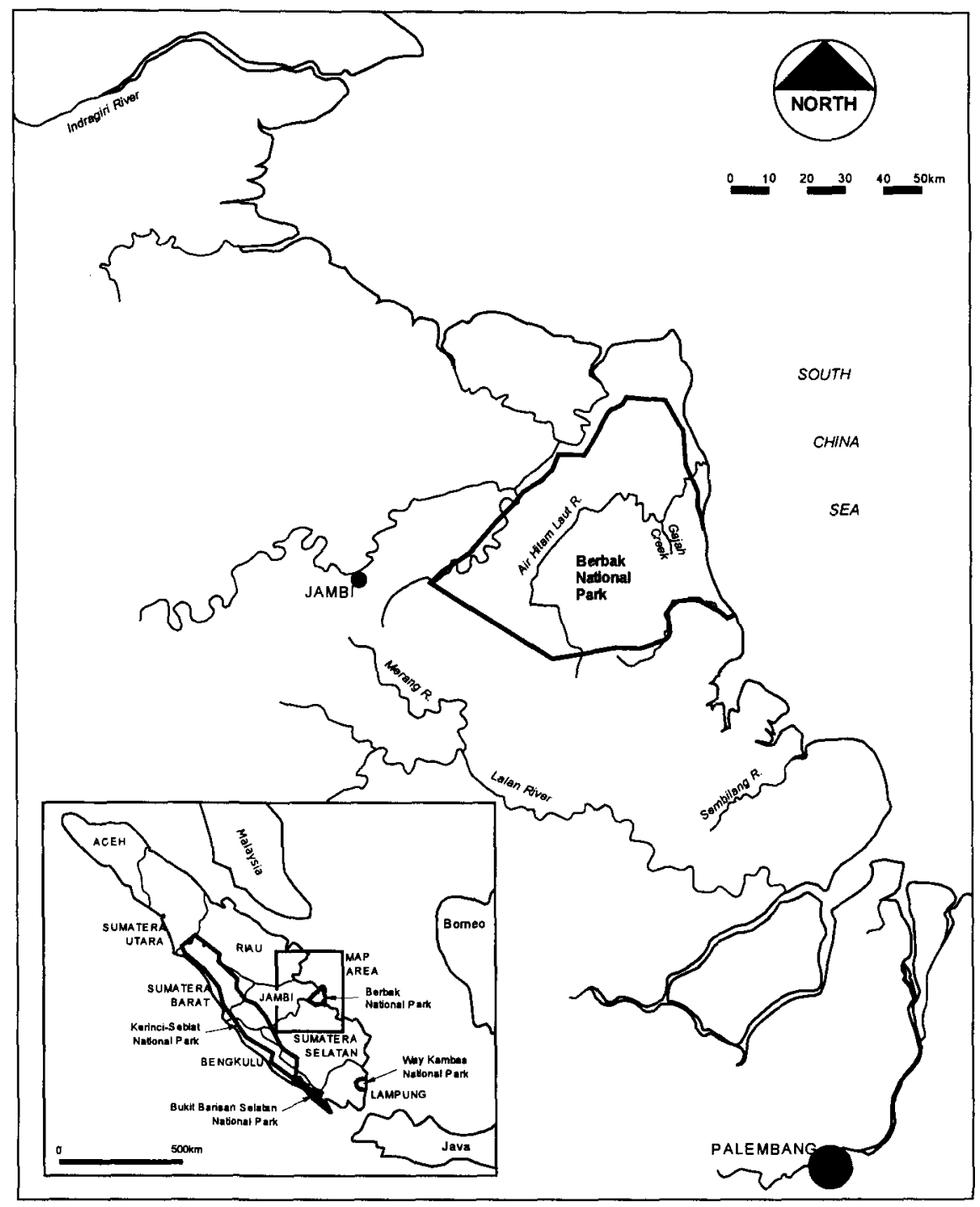


Table 1 Morphometrics of a dead flat-headed cat Prionailurus planiceps from Berbak National Park, Sumatra (September 1996)

\begin{tabular}{lc}
\hline Measure & \\
\hline Sex & Male \\
Weight $(\mathrm{kg})$ & 1.8 \\
Head-body length $(\mathrm{mm})$ & 521 \\
Head length $(\mathrm{mm})$ & 112 \\
Tail length $(\mathrm{mm})$ & 143 \\
Ear length $(\mathrm{mm})$ & 43 \\
Mean testes width (mm) & 11 \\
Mean testes length $(\mathrm{mm})$ & 19
\end{tabular}

Hind-foot length was not recorded. Measures conform to Kitchener et al. (1996) with the exception of ear length, which was measured from the base of ear to the fleshy tip (instead of from the notch in the base of the ear to the fleshy tip).

\section{National University of Singapore}

Eight specimens housed at the Zoological Reference Collection (ZRC) of the School of Biological Sciences, National University of Singapore were examined in July 1998. Collection details and pelage (Table 2) and dental formula were recorded.

All specimens had a uniform rufous-brown upper torso except for skin ZRC.4.1058 (mostly brown) and stuffed specimen ZRC.4.1059 (mostly rufous). Dental formula conformed to previous descriptions for the species (Lekagul \& McNeely, 1977): incisors 3/3; canines 1/1; premolars 2-3/2; molars $1 / 1[\times 2]$.

\section{Discussion}

Flat-headed cats clearly inhabit secondary forest/scrub and primary freshwater swamp forest within lowland coastal floodplains in south-east Sumatra. Habitats differ in vegetation structure and floristics, river structure and extent of human disturbance (Bezuijen et al., 1995, 1997). The flat-headed cat is generally considered to be a piscivorous carnivore (Muul \& Lim, 1970) and most collection records are from riparian habitats (Nowell \& Jackson, 1996). The close proximity of sightings to waterways was a common feature at both localities. The specific habitat requirements of the species are unknown, but records exist from a range of altitudes and habitats, including oil palm plantations (Nowell \& Jackson, 1996), 'open forests, shrubs and rubber plantations' (Irwan, 1992), and mature secondary forest ( $N$. Franklin, Sumatran Tiger Project, pers. comm.; Payne et al., 1985). The localities described in this note would appear to indicate some tolerance to highly modified habitats, as well as occurrence in pristine environments.

There is little published information on the morphology of the species. Data from several specimens from Peninsular Malaysia (Lim \& Rahman, 1961; Muul \& Lim, 1970, 1971; and cited by Lekagul \& McNeely, 1977) and Borneo (Harrison, 1973; Payne et al., 1985) indicate a head-body length of $446-505 \mathrm{~mm}$, a proportionately short tail length of $128-170 \mathrm{~mm}$ (2634 per cent of the head-body length) and a weight range of $1.5-2.2 \mathrm{~kg}$. The male recorded in Berbak National Park was larger than this range (head-body length of $521 \mathrm{~mm}$ ) with a proportionally short tail (27 per cent of head-body length; Table 1). Head-body length and body weight $(1.8 \mathrm{~kg}$; Table 1$)$ suggest the specimen was almost fully grown. Pelage colour of the individuals observed in south-east Sumatra was similar to that of other specimens described from Sumatra, Borneo, Peninsular Malaysia and Thailand (Lim \& Rahman, 1961; Muul \& Lim, 1970; Lekagul \& McNeely, 1977; Payne et al., 1985; Irwan, 1992; Table 2).

There is a lack of information on the current distribution and abundance of the flat-headed cat. Historically, the species was probably widely distributed in suitable habitats in southern and eastern Sumatra, and early specimens were collected from at least three river systems of two provinces in eastern Sumatra (Fig. 1, Table 2). Current camera-trapping projects have confirmed

Table 2 Collection details for flat-headed cat Prionailurus planiceps specimens housed in the ZRC of the National University of Singapore, July 1998

\begin{tabular}{|c|c|c|c|c|c|c|}
\hline ZRC No. & Type & Date & Locality & Collector & Pelage & Sex \\
\hline 4.1058 & Skin, skull & 1915 & Bangnara, Palani, Peninsular Siam* & C. J. Angaard & $\mathrm{r}-\mathrm{b}$ & $?$ \\
\hline 4.1059 & Stuffed, skull & $?$ & $?$ & Selangor Museum & $\mathrm{r}-\mathrm{b}$ & $?$ \\
\hline 4.1060 & Stuffed & 1921 & Johore, Peninsular Malaysia & H. A. Leck & $\mathrm{r}-\mathrm{b}$ & $?$ \\
\hline 4.1061 & Skin & 1924 & Palembang, South Sumatra Provincet & Mr Basapa & $r-b$ & $\mathrm{~F}$ \\
\hline 4.1062 & Skin & 1928 & Indragiri, Riau Provincet & Mr Basapa & $\mathrm{r}-\mathrm{b}$ & $\mathrm{M}$ \\
\hline 4.1063 & Skin, skull & 1930 & Indragiri-Siak, Riau Provincet & $?$ & $\mathbf{r}-\mathrm{b}$ & $?$ \\
\hline 4.1064 & Skin, skull & 1891 & Baram, Borneo & $?$ & $\mathrm{r}-\mathrm{b}$ & $?$ \\
\hline 4.1065 & Skin, skull & 1924 & $?$ & Mr Basapa & $r-b$ & $\mathrm{M}$ \\
\hline
\end{tabular}

* South-east Thailand; t eastern Sumatra.

r-b: rufous-brown. ?: no data available. 
the occurrence of the species in Way Kambas and Kerinci-Seblat National Parks (Anon., 1998; Franklin et al., 1999). It is expected that the species also occurs within Bukit Barisan Selatan National Park, but has not yet been recorded by camera-trapping (M. Kinnaird, Wildlife Conservation Society, pers. comm.). These records illustrate a relatively wide current distribution in the protected areas of eastern, southern and western Sumatra (Fig. 1).

Current status information is limited almost entirely to presence/absence data. The two living individuals described in this note were observed on one system only, the Merang River, in more than 45 nights of spotlighting on nine rivers in eastern Sumatra (Bezuijen et al., 1995, 1997). Berbak National Park has been the focus of scientific research for many years (e.g. de Wulf et al., 1982; Silvius et al., 1984; Giesen, 1990), yet park officers had never observed or heard of the species (Mr Madari, PHPA, pers. comm.). Noted by Nowell \& Jackson (1996) as an area of potential habitat for the species, this specimen appears to be the first confirmed record for Berbak National Park. The species has not been recorded along the nearby Sembilang River (Fig. 1) (GOI-World Bank, 1995). Within Way Kambas National Park, current information on the species is limited to two records of a single animal photographed in 1996 (N. Franklin, pers. comm.).

Within south-east Sumatra, regional fragmentation of riparian habitats and isolation of protected areas increase the importance of unprotected localities with documented sightings of the species. The Merang River appears to be important in this regard. Local fishermen described the species as common (Bezuijen et al., 1997), and it is one of few rivers in the north-east of South Sumatra Province which retains intact peat swamp forest. It also supports a breeding population of an endangered crocodilian (Bezuijen et al., 1998), and its protection would complement a regional strategy proposed for the conservation of coastal wetlands of southeast Sumatra (Davie \& Sumardja, 1997).

\section{Acknowledgements}

Field observations were made during a crocodile research project sponsored by the Indonesian DirectorateGeneral of Forest Protection and Nature Conservation, the Global Guardian Trust, Wildlife Management International Pty Limited, the Crocodile Specialist Group of the IUCN-World Conservation Union, the German Leather Industry Association (Internationaler Reptillederverband-IRV) and the Asian Conservation Sustainable Use Group. Fieldwork in Sumatra was conducted with the support of Ir. Dwiatmo, Dr Samedi and Dr
Tonny Soehartono (PHPA-Jakarta), Pak Sutresna Wartaputra (KSDA-South Sumatra), and Ir. Romon Palete and Pak Madari (KSDA-Jambi). I thank Mrs Yang Chang-Man and Kelvin Lim of the National University of Singapore for granting me access to specimens, and Margaret Kinnaird and Neil Franklin for providing field data on the species. Ecology Australia Pty Ltd provided logistical support for the preparation of this paper. I am grateful to Dr Grahame Webb and Dr Peter Jackson for commenting on a draft manuscript.

\section{References}

Anon. (1998) Rare rabbit and cat captured on film. Fauna $\mathcal{E}$ Flora News (Fauna \& Flora International-Newsletter), 9, 3.

Baillie, J. \& Groombridge, B. (1996) 1996 IUCN Red List of Threatened Animals. IUCN, Gland.

Bezuijen, M.R., Cannucciari, P., Manolis, C., Kadarisman, R., Samedi \& Simpson, B.K. (1995) Field expedition to the Lalan River and its tributaries, South Sumatra, Indonesia, August-October 1995: assessment of the distribution, abundance, status and nesting biology of the False Gharial (Tomistoma schlegelii). Unpublished Report, Wildlife Management International Pty Limited, Darwin.

Bezuijen, M.R., Hartoyo, P., Elliott, M. \& Baker, B.A. (1997) Project Tomistoma. Second report on the ecology of the False Gharial (Tomistoma schlegelii) in Sumatra. Unpublished Report, Wildlife Management International Pty Limited, Darwin.

Bezuijen, M.R., Webb, G.J.W., Hartoyo, P., Samedi, Ramono, W.S. \& Manolis, S.C. (1998) The False Gharial (Tomistoma schlegelii) in Sumatra. In Crocodiles. Proceedings of the 14th Working Meeting of the Crocodile Specialist Group, IUCN-The World Conservation Union, pp. 10-31. IUCN/SSC Crocodile Specialist Group, Gland.

Davie, J. \& Sumardja, E. (1997) The protection of forested coastal wetlands in southern Sumatra: a regional strategy for integrating conservation and development. Pacific Conservation Biology, 3, 366-378.

Franklin, N., Bastoni, Sriyanto, Dwiatmo, S., Manansang, J. \& Tilson, R. (1999) Last of the Indonesian tigers: a cause for optimism. In Riding the Tiger: Tiger Conservation In Human-Dominated Landscapes (eds J. Seidensticker, S. Christie and P. Jackson), pp. 130-147. Cambridge University Press, Cambridge.

Giesen, W. (1990) Berbak Wildife Reserve, Jambi. PHPA/AWB Sumatra Wetland Project Report No. 13. Unpublished Report, Asian Wetland Bureau, Bogor.

GOI-World Bank (1995) The Sembilang Region, South Sumatra: integrated mangrove conservation and land use management plan. A report prepared for the Directorate-General of Forest Protection and Nature Conseroation, Ministry of Forestry. Unpublished Report, ENEX of New Zealand in conjunction with P. T. Manggala Epsilon Sigma, Jakarta. Harrison, J. (1973) An Introduction to the Mammals of Sabah. The Sabah Society, Kota Kinabalu. 
Irwan, F.W. (1992) A Guide to Exotic Mammals of Jambi. University of Jambi, Jambi.

Kitchener, A.C., McOrist, S. \& Wayne, R.K. (1996) Scientific postmortem: a protocol for collection of data and specimens. In Wild Cats. Status Survey and Conservation Action Plan (eds K. Nowell and P. Jackson), pp. 314-316. IUCN/SSC Cat Specialist Group, Gland.

Lekagul, B. \& McNeely, J.A. (1977) Mammals of Thailand. Darnsutha Press, Bangkok.

Lim, B. \& Rahman, I.A. (1961) Observations on the habits in captivity of two species of wild cats, the leopard cat and the flat-headed cat. Malayan Nature Journal, 15, 48-51.

Muul, I. \& Lim, B. (1970) Ecological and morphological observations of Felis planiceps. Journal of Mammalogy, 51, 806-808.

Muul, I. \& Lim, B. (1971) New locality records for some mammals of west Malaya. Journal of Mammalogy, 52, $430-437$.

Nowell, K. \& Jackson, P. (eds) (1996) Wild Cats. Status Survey and Conservation Action Plan. IUCN/SSC Cat Specialist Group, Gland.

Payne, J., Francis, C.M. \& Phillipps, K. (1985) A Field Guide to the Mammals of Borneo. The Sabah Society and World Wildlife Fund Malaysia, Petaling Jaya.

Silvius, M.J., Simons, H.W. \& Verheugt, W.J.M. (1984) Soils, Vegetation, Fauna and Nature Conservation of the Berbak Game Reserve, Sumatra, Indonesia. Research Institute for Nature Management, Arnhem.

de Wulf, R, Supomo, D. \& Kurnia, R. (1982) Berbak Game Reserve Management Plan 1982-1987. UNDP/FAO National Parks Development Project, Field Report 38, INS/78/061. Unpublished Report, United Nations Development Program, Bogor.

\section{Biographical sketches}

Mark Bezuijen, a zoologist, has worked on conservation projects in South-east Asia and northern Australia for the past 15 years, including 2 years studying an endangered crocodilian in Sumatra. He is a member of the Crocodile Specialist Group of the IUCN-World Conservation Union. His specific interests include the conservation biology of crocodilians and cats, and the sustainable use of wildlife. He is currently a zoological consultant in southeastern Australia. 